\title{
Proqramlaşdırmanın Aktual Problemləri Haqqında
}

\author{
Şəfəqət Mahmudova \\ AMEA İnformasiya Texnologiyaları İnstitutu, Bakı, Azərbaycan \\ shafagat_57@mail.ru
}

\begin{abstract}
Xülasə - Bu işdə proqramçıların proqramlaşdırma sahəsindəki bəzi problemləri araşdırılmışdır. Proqramlaşdırma sahəsində çalışan proqramçıların statistik verilənlərinin bəzi göstəriciləri təhlil edilmişdir. Proqram mühəndisliyi sahəsində işləyən proqramçıların forqli xüsusiyyətləri araşdırılmışdır. Proqramçıların istifadə etdiyi müasir texnologiyalar (big data, cloud computing vo s.) və onlar üçün istifadə olunan proqramlaşdırma dilləri barədə məlumat verilmişdir.
\end{abstract}

Açar sözlor-proqramlaşdırma, proqramçı, proqramlaşdırma dillori, böyük verilonlor, verilonlor elmi

\section{GİRIŞ}

Müasir dövrdə informasiya cəmiyyəti inkişaf edərək getdikcə daha böyük vüsət alır. Kompüterlər cəmiyyətdəki bütün proseslərə o cümlədən elmi-tədqiqat işlərinə, iqtisadiyyata təsir göstərərək, ümumilikdə insanın fəaliyyət formasını dəyişdirir və praktikanın yeni sahələrinə daxil olur. İnsanların yeni texnologiyaları öyrənməsi və onu müxtəlif sahələrə tətbiq etməsi müasir yeni sistemlərin və proqramlaşdırma dillərinin yaranmasına və inkişafına səbəb olur.

Proqramlaşdırma ilə proqramçı adlanan mütəxəssislər məşğul olurlar. Proqramçı dedikdə xüsusi riyazi modellər əsasında alqoritmlərin və kompüter proqramlarının hazırlamasıyla məşğul olan mütəxəssis başa düşülür. Proqramçı riyazi model və alqoritmlərin təhlili əsasında hesablama əməliyyatlarının həyata keçirilməsi üçün müxtəlif təyinatlı proqramlar hazırlayır. Verilənlər bazasının strukturunu müəyyənləşdirir, proqramlaşdırmanın avtomatlaşdırılması üçün alqoritmlər işləyir və $\mathrm{s}$. [1].

Proqramlaşdırmada proqramçının həm praktiki təcrübəsi, həm də ideyası əsasdır. Proqramçıları əsasən üç kateqoriyaya bölmək olar:

- tətbiqi proqramçı;

- sistem proqramç1;

- Web proqramçı.

Qeyd edək ki, proqramçıların da özünəməxsus problemləri vardır və bunlardan bəziləri aşağıda qeyd edilmişdir:

- Proqramın yazılışı prosesində yaranan çətinlikləri şəxsi dram kimi qəbul edirlər;

- Proqramlaşdırma prosesinə mexanistik yəni, ürəksiz, sağlam düşüncəsiz və $\mathrm{s}$. kimi baxırlar;

- Bütün lazımı məlumatlara malik olmadan məsələni həll etməyə cəhd göstəririlər;
- Məsələni sifarişçinin təsvir etdiyi kimi həll etmirlər və s. $[2,3]$.

\section{PROQRAMÇILARIN BӘZİ PROBLEMLӘRİ}

Proqramçılar haqqında bəzi məlumatlar verək. Qeyd edək ki, statistik məlumatlar əsasında Stack Overflow sorğu agentliyi tərəfindən (stackoverflow.com) proqramlaşdırma ilə məşğul olan proqramçıların yaş həddi, cinsi, iş stajı və s. [4] göstəriciləri üzrə statistik təhlil aparılır. Şəkil 1-dəki diaqramdan göründüyü kimi, proqramçıların 2016-c1 il statistikasına əsasən (25000 proqramçı) yaş intervalı 25-29 arasında olanlar faiz hesabıyla üstünlük təşkil edirlər.

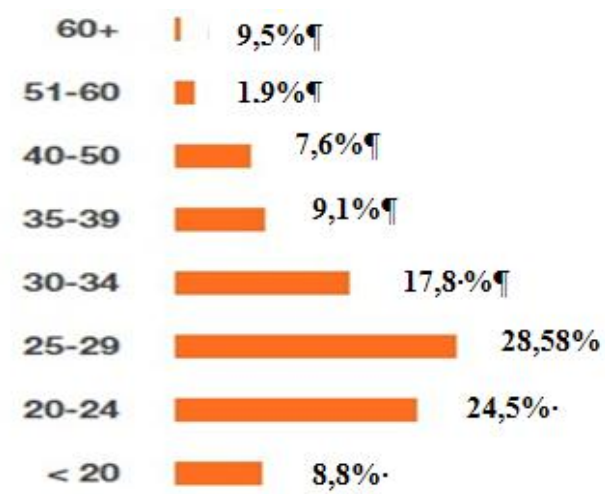

Şəkil 1. Proqramçıların yaş göstəriciləri

Şəkil 2-dəki diaqramdan göründüyü kimi proqramlaşdırma sahəsində işləyən proqramçıların əksəriyyətini faiz hesabıyla kişilər təşkil edirlər.

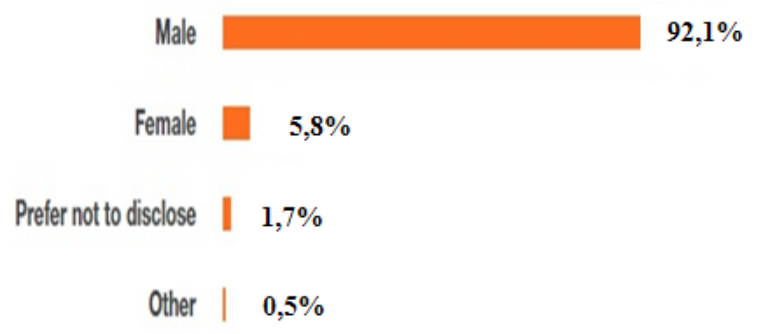

Şəkil 2. Proqramçıların cinsi mənsubiyyətinin göstəriciləri

Şəkil 3-dəki diaqramda proqramlaşdırma ilə məşğul olan proqramçıların iş stajı barədə məlumat verilmişdir. Diaqramdan göründüyü kimi iş stajı 2-5 intervalında olan proqramçıların faiz hesabı maksimumdur. 


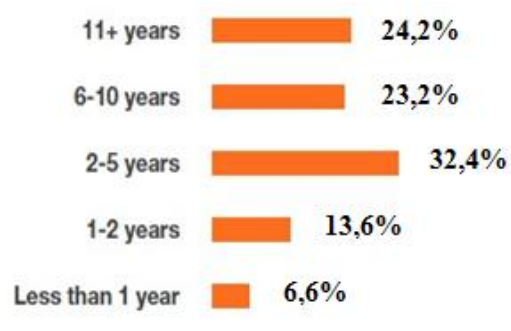

Şəkil 3. Proqramçıların iş stajının göstəricisi

Şəkil 4-də proqramçıların istifadə etdiyi proqramlaşdırma dillərinin reytinqini göstərən diaqramdan göründüyü kimi Javascrip dilindən istifadə edənlərin faiz hesabı yüksəkdir.

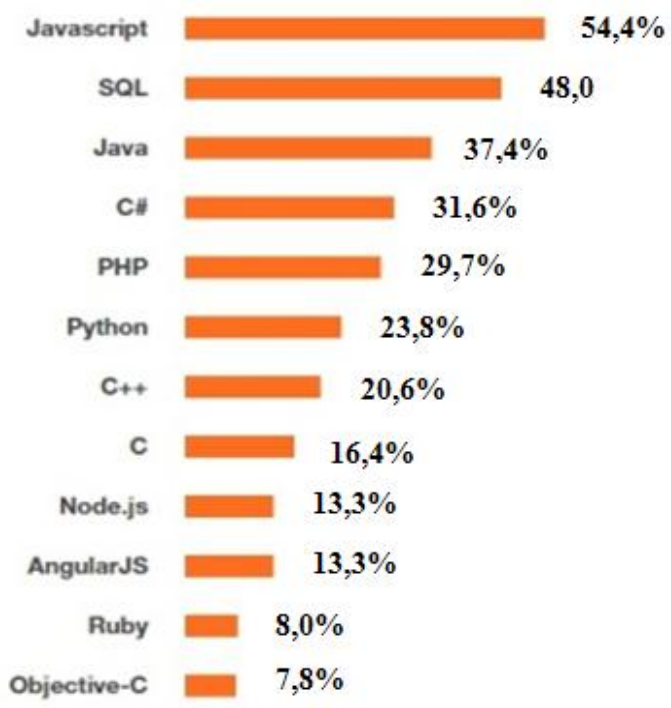

Şəkil 4. Proqramlaşdırma dillərinin göstəriciləri

Proqramlaşdırma ilə məşğul olan proqramçılar peşələri ilə əlaqədar bir çox xəstəliklərə məruz qalırlar. Onların işi oturaqdır və az hərəkətlidir. Bununla əlaqədar proqramçılar artıq çəki ola bilirlər, onlarda yüksək arterial təzyiq, ürəkdamar, ateroskleroz və s. kimi xəstəliklər yarana bilir. Lənglik dayaq-hərəkətedici aparatın xəstəliklərinə gətirir, belələrinə misal olaraq osteoxondroz, radikulit, artrit və s. göstərmək olar. Bu xəstəliklərin profilaktikası üçün aktiv istirahətin təşkili zəruridir, proqramçı idmanla məşğul olmalı, çoxlu piyada gəzməlidir. Həmçinin işdə fasilələrdə müəyyən idman hərəkətləri etmək lazımdır. Klaviaturayla daimi iş barmaqlarda xroniki yorğunluq yaradır, sonra bu, barmaqlar və oynaqların ciddi xəstəliklərinə səbəb ola bilir. Proqramçının işi əsəb və psixi xəstəliklərin mənbəyidir. Vacib məlumatların itməsi, kompüterin işində nasazlığın yaranması proqramçının stress vəziyyətə düşməsinə səbəb olur və bu da onun əsəb sistemini korlayır.

Qeyd etmok lazımdır ki, sistem proqramlaşdırması daimi riyazi hesablamalar tələb etdiyindən proqramçılarda bəzən psixi xəstəliklərə gətirib çıxarır və bunun müalicəsi artıq məcburi qaydada həyata keçirilir. Statistika göstərir ki, texniki ali məktəblərin böyük kurslarında oxuyan bəzi tələbələr bu işə o dərəcədə aludə olurlar ki, hətta onların psixikası pozulur. Sağlam yuxu və proqramçını dəstəkləyən mehriban ailəsi bu vəziyyətdə onun ən yaxşı köməkçidir. Proqramçının, göründüyü kimi sakit işi əslində çox təhlükəlidir, amma təhlükələrin düzgün qiymətləndirilməsi və sağlam həyat tərzi onları minimuma qədər azaldır [5].

Hərbi işlərdə yeni informasiya texnologiyaların işlənməsi və idarəedilməsi üzrə yaxşı proqramçılara böyük tələbat vardır. $\mathrm{Bu}$ sahə üzrə istiqamətlər müxtəlifdir: məlumat şəbəkələrinin qurulmasından tutmuş, hərbi hissənin həyətlərindəki anbarlarda aparılan hesablamalara qədər.

Proqramçılar mürəkkəb məsələləri yaxşı səviyyədə həll etməyə çalışırlar [6].

Proqramçı ilə proqram mühındisliyi (PM) sahəsində işləyən proramçılar arasında bir sıra fərqlər vardır. Onlardan bəziləri aşağıda qeyd olunmuşdur.

\section{Proqramçı tam proqram yazır.}

PM-da mühəndis-proqramçı proqram komponentlərini yazır, belə ki, bunlar sistemin qurulması üçün proqram təminatının başqa istehsalçıları tərəfindən yazılmış komponentlərlə birləşdirilə bilər. PM-da yazılan komponentlər başqa proqramçılar tərəfindən dəyişdirilə bilər. PM-da əgər proqramçı layihəni uzun müddətə tərk edirsə, bu halda sistemin müxtəlif versiyalarının işlənməsində başqa proqramçılardan istifadə oluna bilər.

2. Proqramçı üçün proqramlaşdırma ilk növbadə şaxsi faaliyyatdir.

PM-da bu əsasən komandanın fəaliyyətidir.

3. Proqramçı üçün proqramlaşdırma yalnız proqram təminatının hazırlanmasının aspektlarindon biridir.

PM-da böyük proqram sistemləri mühəndis-texniki təcrübə əsasında başqalarına analoji olaraq hazırlanır [7].

Proqramçıların fəaliyyət göstərdiyi proqramlaşdırma sahələri genişdir. Proqramlaşdırmadan müxtəlif proqram təminatının işlənilməsi, saytların yaradılması, ofis ișinin təşkili və s. istifadə olunur. Aşağıda bəzi sahələr qeyd olunmuşdur:

- elektron dövlətin qurulmasında;

- biznes və özəl sahələrdə;

- hərbi, aerokosmik, robot texnikası sahələrində;

- saytların və Veb əlavələrin işlənilməsində;

- ofis proqramlarının işlənilməsində;

- mobil telefonlar üçün əlavələrin işlənilməsində;

- dəbdə olan oyunların işlənilməsində və $\mathrm{s}$.

$\mathrm{Bu}$ proqramlaşdırmanın mümkün tətbiq sahələrinin tam siyahısı deyildir. Bizim dövrdə demək olar ki, bütün işlər praktiki olaraq proqramlaşdırılır, buna görə proqram məhsullarının istehsalçısının peşəsi ən çox tələb edilənlərdən sayilır.

Proqramlaşdırmanın istifadə edildiyi çox sahələrdə yeni səhifədən başlamağa ehtiyac yoxdur, çünki kifayət qədər yeni texnologiyalar vardır və onlardan uğurla istifadə etmək olar. 


\section{PROQRAMLAȘDIRMADA İSTIFADO \\ OLUNAN MÜASIR TEXNOLOGIYALAR}

Hər sahədə olduğu kimi proqramlaşdırma sahəsində də müasir texnologiyalardan istifadə olunur. Onlardan bəziləri aşağıda gösrərilmişdir:

- Böyük verilənlər (Big Data);

- Verilənlərin elmi (Data Science);

- Bulud hesablamaları (Cloud computing);

- Şəbəkə hesablamaları (Grid Computing) və s.

\section{A. Big Data texnologiyast}

İnformasiya texnologiyalarında böyük verilənlərstrukturlaşdırılmış və strukturlaşdırılmamış əhəmiyyətli və müxtəlifl böyük həcmli verilənlərin işlənilməsi üçün yanaşmalar, alətlər və metodların seriyasıdır və fasiləsiz artım şəraitində effektiv nəticələrin insan tərəfindən alınması üçün emal olunur].

Big Data sahəsində ən çox işlənilən Hadoop aləti, Python, Java və R və s. proqramlaşdırma dili hesab olunur. Bu sahədə istifadə olunan ən yaxşı proqram paketi və proqramlaşdırma dillərindən bəziləri aşağıda qeyd olunmuşdur [8].

1. Julia yeni dil olmasına baxmayaraq artıq populyarlıq qzanmışdır və onun paylanmıș sistemlərdə istifadəsi xüsusilə effektli hesab edilir.

2. SAS (Statistical Analysis System) proqram paketindən böyük verilənlərin analizində istifadə olunur.

3. Python (rus dilində piton) kodun sadə oxunmasına yönəldilmiş ümumi təyinatlı yüksək səviyyəli proqramlaşdırma dilidir. Eyni zamanda standart kitabxanasına böyük həcmli faydalı funksiyalar daxildir.

4. $\mathrm{R}$ qrafik və statistik məlumatların işlənilməsi və s. üçün istifadə olunan proqramlaşdırma dilidir. $\mathrm{Bu}$ dil Bell Labs korporasiyasında $\mathrm{C}$ dilinə analoji olaraq hazırlanmışdır.

5. Scala dili verilənlərin alimi (Data scientists) üçün istifadə olunur.

6. MATLAB böyük həcmli ədədlərlə işləmək üçün istifadə olunan tətbiqi proqramdir.

7. HiveQL sorğu dilidir, Apache Hive və Apache Hadoop üçün nəzərdə tutulub.

8. Pig Latin dili Apache Pig platforması üçün nəzərdə tutulub. Hadoop MapReduce-də yerinə yetirilə bilər [9].

Qeyd edək ki, ABŞ-da Big Data Universiteti fəaliyyyət göstərir. Burada kurslarda müxtəlif proqramlaşdırma dilləri və digər fənlər tədris olunur.

\section{B. Verilanlar elminda proqramlaşdırma}

2010-cu idən başlayaraq verilənlərin alimi tələb olunan ən sərfəli, yüksək maaşlı və perspektivli mütəxəssislərdən biri hesab edilir [10].

Verilənlərin elmi informatikanın bölməsidir, rəqəm tipli verilənıərin analizi, emalı və b. problemləri öyrənir. Yüksək səviyyəli paralellik şəraitində böyük həcmli verilənlərin işlənilməsi, statistik metodları, verilənlərin intellektual analiz və süni intellekt metodları, verilənlər bazasının layihələndirilməsi və işlənilməsi metodlarını öyrənir və onların inteqrasiyasını təmin edir.

Böyük verilənlərin analitikası verilənlər elminnin diqqət mərkəzində durur. Bir çox dövlət və özəl təşkilatlar böyük həcmdə müxtəlif verilənləri toplamağa başladılar, belə ki, bunlar problemlər haqqında faydalı məlumatları özündə saxlaya bilir. Məsələn, milli kəşfiyyat, kiber-təhlükəsizlik, marketinq və tibbi informatikada böyük verilənlər texnologiyasından istifadə edilməsi işin səmərələliyinin yüksəlməsinə səbəb oldu.

$\mathrm{Bu}$ fənn ilk dəfə olaraq 1966-c1 illərdə formalaşmağa başlamışdır. $\mathrm{Bu}$ termindən ilk dəfə olaraq 1974 -cü ildə danimarkalı alim Peter Naur öz kitabında istifadə etmişdir [11].

O verilənlər elmini rəqəm tipli məlumatların həyat dövrünü öyrənən fənn kimi müəyyən etdi və başqa fənlərlə əlaqəsini aydınlaşdırdı.

2000 -ci illərdə Data Science termininı amerikalı professor Vilyam Klivlend (William S. Cleveland) dahada inkişaf etdirdi.

Müasir cəmiyyətin bütün sahələrində məlumatların böyük həcminin analizi ilə Big Data məşğul olur, problemləri araşdırır və verilənlərin elmi haqqında fikirləri formalaşdırır. Bu sahədə modelləşdirmə və proqnozlaşdırma, müasir proqram sistemləri, proqramlaşdırma, riyazi metodlardan və s. istifadə olunur [12].

Data Science sahəsində 2016-c1 ildə istifadə olunan proqramlaşdırma dillərinin reytinqini göstərən diaqram şəkil 5-də göstərilmişdir [13]. Diaqramdan göründüyü kimi SQL digərləri ilə müqayisədə üstünlük təşkil edir.

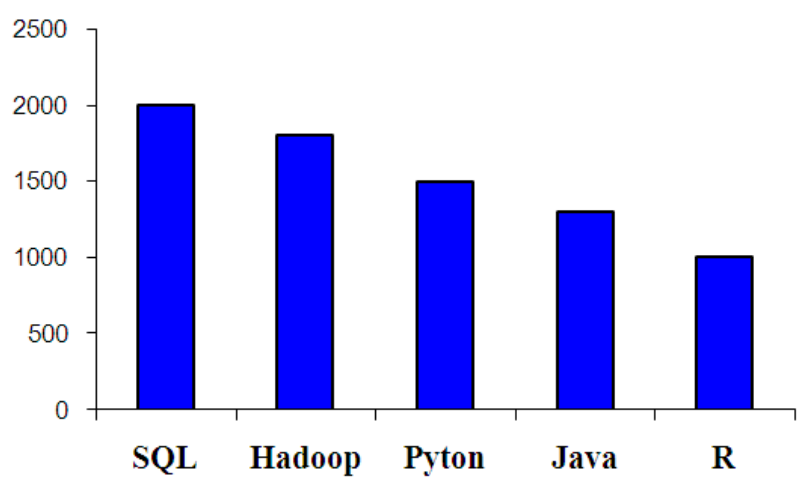

Şəkil 5. Data Science sahəsində istifadə olunan proqramlaşdırma dillərinin reytinqini göstərən diaqram

\section{Bulud texnologiyast}

Bulud texnologiyass (Cloud computing) kompüter texnologiyalarının infrastrukturunun və proqram təminatının bilavasitə şəbəkə mühitində yaradılmasını və istifadə edilməsini təmin edir. $\mathrm{Bu}$ texnologiyanın köməyi ilə istifadəçinin məlumatları bulud sistemlərində saxlanılır, emal edilir, emal proqramlarının işə salınması və nəticələrə baxılması təmin edilir [14]. 
İnformasiya texnologiyalari (İT) üzrə bazarı təhlil və tədqiq edən analitik mərkəz (IDS-International Data Corporation, Freminqem, Massaçusets, ABŞ) 2014-cü ildə təqdim etdiyi proqnozlara görə, bulud texnologiyalarının yaradılmasına sərf olunan xərclər 56.6 milyarddan (2014-cü il) 127.5 milyard (2018-ci il) dollaradək artacaq. 2017-ci ildə IT sahəsində sərf ediləcək illik xərclərin 17\%-i "bulud texnologiyaları"nın payına düşəcək [15].

Bulud texnologiyası üçün istifadə olunan proqramlaşdırma dillərinin bəziləri aşağıda göstərilmişdir [16]:

- Java;

- ASP.NET;

- PHP;

- Python;

- Ruby;

- Perl vəs.

\section{Grid hesablamalarl}

Grid hesablamaları (Grid Computing) - kommunikasiya texnologiyasının köməyi ilə mürəkkəb məsələnin həllində istifadə olunan və müxtəlif təşkilatlarda yerləşən çoxsayl hesablama qovşaqlarının (server, kompyuter və s.) birləşməsi ilə yaradılan paylanmış hesablama sistemidir [17].

Grid Computing -də istifadə olunan bəzi proqramlaşdırma dilləri aşagıda qeyd olunmuşdur:

- Java;

- $\mathrm{C}$;

- WSDL (Web Services Description Language);

- XML;

- Python va s.

\section{NəTIC๐}

$\mathrm{Bu}$ işdə proqramçılar və onların problemləri, müasir texnologiyalardan istifadə etmələri və $\mathrm{s}$. barədə təhlillər aparılmışdır.

Azərbaycanda da PM-nin inkişafi üçün bir sıra tövsiyyələr vermək olar. Onlardan bəziləri aşağıda göstərilmişdir:

- İlk növbədə uşaqlarda və gənclərdə PM-yə maraq yardilmalıdır;

- Məktəblərdə proqram mühəndisliyi üzrə dərslərin keçirilməsi, əlavə məşğələlərin aparılması, gənc proqramçılar məktəbinin yaradılması və $\mathrm{s}$. bu məqsədə xidmət etməlidir;

- Ali təhsil müəssisələrində PM fəni güclü tədris edilməlidir. Çünki, bu sahədə peşəkar mütəxəssislərin hazırlanmasına böyük ehtiyac vardır;

- Respublika səviyyəsində PM sahəsində dövlət qanunu və sərəncamların hazırlanması və qüvvəyə minməsi zəruridir;
- Proqram mühəndisliyi üzrə pespublika səviyyəsində ümumi konsepsiya hazırlanmalıdır;

- PM üzrə xarici ölkələrdə çalışan azərbaycanlı mütəxəssislər bu işə cəlb edilməli və onların bilik və təcrübəsindən istifadə edilməlidir;

- Xarici ölkələrin PM sahəsindəki təcrübəsi öyrənilməlidir. Xarici ölkələrdə kadr hazırlığı həyata keçirilməlidir və $\mathrm{s}$.

Şəkil 6-da PM üzrə 2016-c1 ildə müxtəlif ölkələrdə keçirilən beynəlxalq konfransların sayını göstərən diaqram verilmişsir.
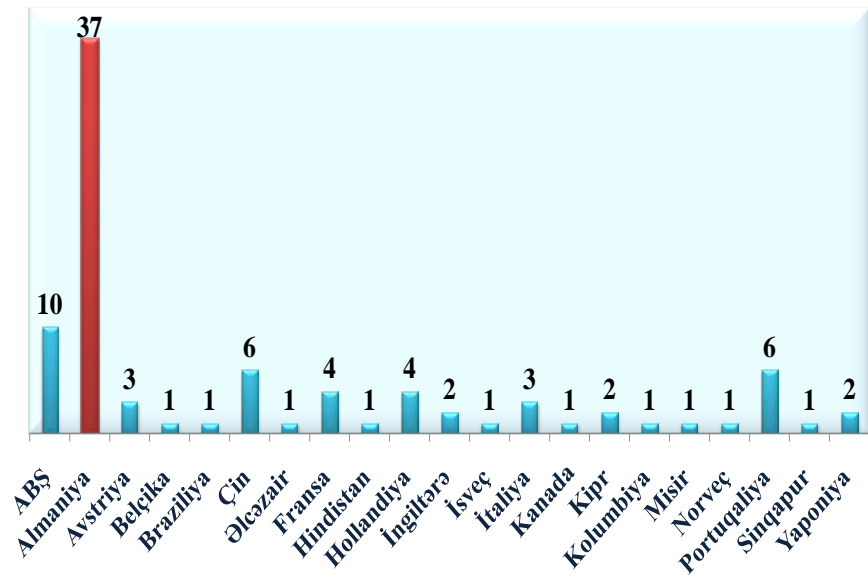

Şəkil 6. Proqram mühəndisliyi üzrə 2016 -c1 ildə müxtəlif ölkələrdə keçirilən beynəlxalq konfransların sayı

$\mathrm{Bu}$ diaqramdan göründüyü kimi Azərbaycan Respublikasının adı bunların arasında yoxdur. Amma ümid etmək olar ki, tezliklə Respublikada da bu tipli konfranslar keçiriləcək.

\section{ӘDӘВIYYAT}

[1] S. Mahmudova, K. Məmtiyev, "Proqramlaşdırma və onun inkișaf mərhələləri", 2011, $112 \mathrm{~s}$

[2] В.Солуянов, «Проблемы программистов», http://www.cmsmagazine.ru/library/items/programming/problem y-programmistov/

[3] В. А. Рожников, «Психология программирования: Цели, проблемы, перспективы», № 3, 2014, стр. 18-21.

[4] Stack Overflow: http://ru.stackoverflow.com/

[5] «Болезни программистов, лечение и профилактика», http://www.tiensmed.ru/programmer.html

[6] Н. Uoppen, «Алгоритмические трюки для программистов», $2014,506 \mathrm{c}$

[7] "Software Engineering Vs. Programming", https://www.ics.uci.edu/ ziv/ooad/intro_to_se/tsld008.htm

[8] M. Najafabadi, F.Villanustre, T. Khoshgoftaar, N. Seliya, R. Wald, E. Muharemagic, "Deep learning applications and challenges in big data analytics", Journal of Big Data, USA, 2015, vol 2, №1, pp. 1-21.

[9] "Which freaking big data programming language should I use?", http://www.infoworld.com/article/3049672/applicationdevelopment/which-freaking-big-data-programming-languageshould-i-use.html 
[10] "Analytics, Big Data, and Data Science Courses", https://bigdatauniversity.com/

[11] "Data science", https://en.wikipedia.org/wiki/Data_science

[12] F. J. Smith, "Data Science as an Academic Discipline", Data Science Journal, 2006, vol. 5, No.19, pp. 163-180.

[13] R. Muenchen, "The Popularity of Data Science Software”, http://r4stats.com/articles/popularity/

[14] D. Castro, How Much Will PRISM Cost the U.S. Cloud Computing Industry? |www2.itif.org/2013-cloud-computingcosts.pdf
[15] R.M Alguliyev, R.K. Alekperov, "Cloud Computing: Modern State, Problems and Prospects", Telecommunications and Radio Engineering, 2013, vol.72, no.3, pp. 255-266.

[16] P. Mell, T.Grance, The NIST definition of cloud computing, 2010, www.nist.gov/itl/ cloud/upload/cloud-def-v15.pdf

[17] I. Foster, C. Kesselman, "The Grid: Blueprint for New Computing Infrastructure", Morgan Kaufman, San Fransisko, $1999,438 \mathrm{p}$. 